\title{
Intrapopulation variations in diet and habitat use in a marine apex predator, the broadnose sevengill shark Notorynchus cepedianus
}

\author{
Kátya G. Abrantes ${ }^{1,3, *}$, Adam Barnett ${ }^{2}$ \\ ${ }^{1}$ Coastal and Estuary Ecosystem Ecology Laboratory, School of Marine and Tropical Biology, James Cook University, \\ Townsville, Queensland 4811, Australia \\ ${ }^{2}$ Tasmanian Aquaculture and Fisheries Institute, Marine Research Laboratories, Hobart, Tasmania 7053, Australia \\ ${ }^{3}$ Present address: Department of Earth and Environmental Sciences, Katholieke Universiteit Leuven, Celestijnenlaan 200E, \\ 3001 Heverlee, Belgium
}

\begin{abstract}
Intrapopulation differences in diet and/or movement are important for understanding the role mobile predators play in different systems. However, ecological studies traditionally overlook individual differences. $\delta^{13} \mathrm{C}$ and $\delta^{15} \mathrm{~N}$ were used in conjunction with diet and movement information to identify intrapopulation differences in diet and movement patterns of the apex predator broadnose sevengill shark Notorynchus cepedianus in southeast Tasmania. Sevengill samples from 3 inshore and 3 offshore sites were collected, and $\delta^{13} \mathrm{C}$ and $\delta^{15} \mathrm{~N}$ compared between sites, sizes and sexes. Individuals captured offshore had lower $\delta^{15} \mathrm{~N}$ than those captured inshore, indicating some degree of spatial segregation. Sevengills also had variable $\delta^{13} \mathrm{C}$ and $\delta^{15} \mathrm{~N}$ within coastal habitats, suggesting intrapopulation differences in diet or migration schedules. In comparison to their main prey, most individuals had $\delta^{15} \mathrm{~N}$ lower than expected for a top predator, also suggesting that they do not reside permanently in these areas, as their tissue was not in isotopic equilibrium with their known prey. This is in agreement with tracking data that showed seasonal use of coastal areas, with most animals leaving for the colder months but returning the following year. There was also a group of females with relatively high $\delta^{13} \mathrm{C}$ that suggests greater association to coastal habitats, again in agreement with tracking data, as some tagged females remained in the coastal areas over winter. Overall, together with diet and tracking information, results indicate that there are differences in movement and possibly diet in this sevengill population. This multimethods approach allowed a better understanding of sevengill ecology than the use of any one of the techniques alone.
\end{abstract}

KEY WORDS: Chondrichthyans $\cdot$ Coastal $\cdot$ Diet $\cdot$ Movement $\cdot$ Stable isotope $\cdot$ Tracking

\section{INTRODUCTION}

Large mobile marine predators are often elusive, have large and/or unknown home ranges and frequently move between distanced habitats, making the study of movement patterns and food web dynamics difficult. These predators can link different systems by connecting spatially separated food webs, therefore transferring energy between distant habitats and playing an important role in food web dy- namics and stability in more than one system (Estes et al. 1998, Quevedo et al. 2009, Matich et al. 2011). Hence, knowledge of both movement patterns and trophic ecology across their distribution range is crucial to understanding their importance in the different communities they occupy.

Electronic tagging techniques such as acoustic telemetry and satellite technology are useful for studying animal movement. However, acoustic tracking can normally only cover a portion of the range of 
habitats used due to the high costs involved in setting up and maintaining an appropriate acoustic array. Satellite tracking also has some limitations, mainly related to the limited battery life, and for marine animals it is most appropriate for species that are at the surface long enough for the information to be transmitted to the satellites. Different groups of individuals can also have different movement patterns, seasonally moving between different habitats (Hindell et al. 2003, Austin et al. 2004, Weng et al. 2005), and hence a large number of individuals of both sexes and all size classes need to be tagged for an accurate estimation of habitat use and movement patterns of a population.

Stable isotope analysis has also been used to study animal movement (Hobson 1999). This fast and easyto-use method gives time-integrated information on the assimilated diet of a consumer. Although it is traditionally used to study diets or to determine the ultimate sources of nutrition supporting food webs (e.g. Connolly et al. 2005, Alfaro et al. 2006), it is also useful to study movement between areas and habitats, when the food sources in the different areas have distinct stable isotopic composition (Herzka 2005). Unlike other tracking techniques, which look at where the animal goes after the tagging event, stable isotope analysis provides information on where the animal has been in the time period before capture.

Stable isotopes have been successfully used in the study of animal movement in a range of systems, both terrestrial (e.g. Cerling et al. 2006) and aquatic (e.g. Best \& Schell 1996). For aquatic systems, most studies available were conducted in freshwater or estuarine habitats (e.g. Cunjak et al. 2005, Herzka 2005), and studies on marine systems are still somewhat limited. Examples are however available, mainly related to offshore versus inshore foraging or to migrations through well defined isoscapes. These are mainly related to marine mammals and birds (e.g. Best \& Schell 1996, Cherel et al. 2009), and studies on movement patterns of fish and sharks in particular are still lacking. In addition, with the exception of marine birds (e.g. Ramos et al. 2009, Jaeger et al. 2010), few studies have combined stable isotope and tracking techniques to address movement and/or trophic ecology for marine animals (Cunjak et al. 2005, Papastamatiou et al. 2010, McClellen et al. 2010).

Broadnose sevengill sharks Notorynchus cepedianus are large mobile predators with a wide temperate distribution, that generally occur from inshore coastal areas to the continental shelf at depths up to 200 m (Last \& Stevens 2009, A. Barnett unpubl. data).
They are seasonally abundant in shallow coastal habitats (Ebert 1989, Lucifora et al. 2005, Barnett et al. 2010a), where they feed mostly on other elasmobranchs, marine mammals and teleosts (Ebert 1989, 1991, Lucifora et al. 2005, Braccini 2008, Barnett et al. 2010b). Recently, an intensive 3-yr study on sevengill shark ecology was conducted in 2 coastal habitats of southeast Tasmania, Australia, where information on diet, population structure, habitat use and movement patterns was collected (Barnett et al. 2010a,b,c, 2011). Thus, the current study provides a unique opportunity to use stable isotope analysis in conjunction with diet and movement information to further study the ecology and intrapopulation variations in diet and/or movement for these large apex predators. Understanding the causes and consequences of intrapopulation differences in movement and dietary patterns can provide important insights into factors that influence the spatial dynamics and resource use of apex predator populations (Jorgensen et al. 2009, Matich et al. 2011). However, population ecology studies have traditionally overlooked individual differences in diet and movement.

Sevengills from the 2 main coastal locations considered in the present study (Norfolk Bay and the Derwent Estuary) show relatively low dietary and spatial overlap, suggesting resource partitioning and/or localised site-fidelity over relatively fine spatial scales $(\sim 30 \mathrm{~km})$ (Barnett et al. 2010b, 2011). Preferential or specialist foraging behavior was also suspected in some individuals, but since most $(76 \%)$ stomachs sampled only contained one or 2 prey items, and because sevengills in general were found to consume a wide range of prey, individual variations in foraging behavior were hard to determine from stomach content data alone (Barnett et al. $2010 b)$. Since stable isotope analysis provides longterm diet information, as opposed to the short-term snapshot that is acquired by the analysis of stomach contents, this technique may be more appropriate to investigate intrapopulation differences in diet (Vander Zanden \& Rasmussen 2002, Matthews \& Mazumder 2004). Intrapopulation differences in diet and habitat use by sevengill sharks can have important consequences for the local community and foodweb dynamics, and as such must be considered when determining the functional role of this species (Matich et al. 2011).

The objective of this study was to use stable isotope analysis of carbon and nitrogen in conjunction with diet and movement information to identify any intrapopulation differences in diet and residency patterns of sevengill sharks in southeast Tasmania. A large 
sample size is considered, making this a comprehensive study of habitat and resource use of the sevengill shark population in southeast Tasmania. The specific aims are: (1) to determine if there are detectable differences in stable isotope composition between sites, including inshore and offshore sites, which can be used as indicators of the level of connectivity between areas; and (2) to use stable isotopes in conjunction with stomach content and tracking data to identify intrapopulation differences in diet and movement patterns in 2 coastal locations of southeast Tasmania.

\section{MATERIALS AND METHODS}

\section{Study sites}

This study was conducted in southeast Tasmania, Australia (Fig. 1). We sampled 2 main study sites: the Derwent Estuary and Norfolk Bay (Fig. 1). We also collected additional sevengill shark samples from Storm Bay and from deeper, offshore sites around the Maatsuyker Islands, close to Pedra Branca and on the continental shelf off eastern Tasmania (Fig. 1).

The Derwent River runs through the City of Hobart (population: 250000 ) and flows into Storm Bay before opening out to the continental shelf (Fig. 1). It

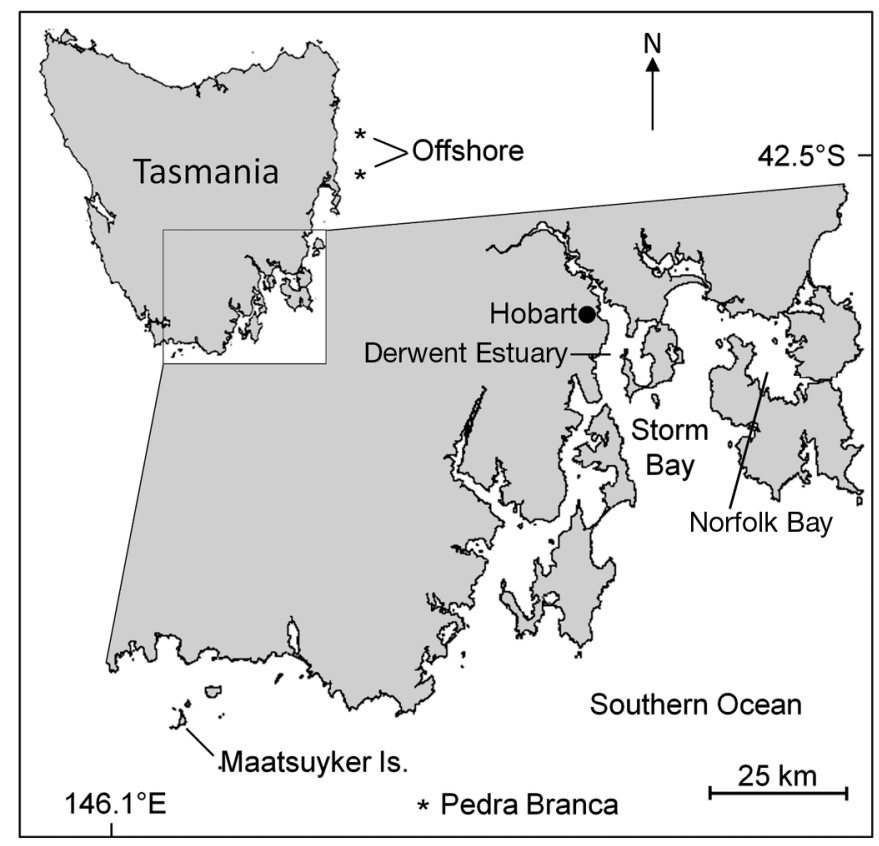

Fig. 1. Sampling sites in Tasmania for stable isotope analysis of sevengill shark Notorynchus cepedianus. Coordinates are for the large scale map consistently reaches depths of 20 to $30 \mathrm{~m}$. Norfolk Bay is a relatively shallow (average depth $15 \mathrm{~m}$; maximum depth $20 \mathrm{~m}$ ), semi-enclosed bay with an area of $\sim 180 \mathrm{~km}^{2}$, that connects to Frederick Henry and Storm Bay (Fig. 1). Storm Bay, a more open area, was also sampled at 20 to $30 \mathrm{~m}$ depth. The Maatsuyker site is located close to the Maatsuyker Islands, $\sim 10 \mathrm{~km}$ off the south coast of Tasmania, at $\sim 90 \mathrm{~m}$ depth. The Pedra Branca site was located in the proximity of a steep rocky outcrop of the same name, $\sim 26 \mathrm{~km}$ south of Tasmania (Fig. 1). Here, we sampled sharks from the edge of the continental shelf, at depths of $\sim 150 \mathrm{~m}$. We also sampled 2 additional sites on the edge of the continental shelf off the east coast of Tasmania, also at depths of $150 \mathrm{~m}$ (Fig. 1). Hereafter, these 2 sites are collectively called 'Shelf'.

\section{Animal collection}

We sampled sevengill sharks from the Derwent Estuary and Norfolk Bay between January 2007 and February 2009. Sharks were captured with bottomset long lines (see Barnett et al. 2010a), brought on board, measured (total length [TL]) and sexed. The sexual maturity of males was determined by testing for clasper calcification. Muscle samples were removed from the flank just behind the dorsal fin with an $8 \mathrm{~mm} \varnothing$ biopsy punch. All animals were returned alive and well to the water. Whenever possible, we collected samples from sharks of both sexes, while encompassing the full range of sizes available at each site. Collections were carried out in spring (September to November, when catch rates increase in these areas; Barnett et al. 2010a), summer (December to February, time of peak abundance), autumn (March to May, just prior to a decrease in catch rates) and winter (June to August, period of very low catches).

Muscle samples from the main prey species were also collected from these 2 coastal sites between November 2008 and February 2009. For chondrichthyans, samples were removed as described for sevengill sharks. Teleosts were caught with gill nets and rod and reel, and were killed by brain spiking. Squid were captured with rod and reel and killed by immersion in ice slurry. Samples were immediately placed in ice until transport to the laboratory, and frozen at $-20^{\circ} \mathrm{C}$ until analysis. Muscle samples (preserved frozen) of Australian fur seals Arctocephalus pusillus doriferus from the Derwent Estuary were obtained from the Tasmanian Department of Primary Industries, Parks, Water and Environment. 
Muscle tissue from sevengill sharks was also obtained aboard commercial fishing vessels targeting gummy sharks Mustelus antarcticus and operating in Storm Bay and offshore around the Maatsuyker Islands, Pedra Branca, and in the continental shelf off the east coast of Tasmania in November 2008 (Fig. 1). All samples were frozen upon collection.

\section{Sample processing}

Only white muscle tissue was used in the analyses. Since tissue lipid content affects its $\delta^{13} \mathrm{C}$ (DeNiro \& Epstein 1977, McConnaughey \& McRoy 1979), lipids were removed for species with high lipid content: Australian fur seal Arctocephalus pusillus doriferus, southern conger eel Conger verreauxi, brown trout Salmo trutta and yellow-eye mullet Aldrichetta forsteri. Lipids were removed with a chloroform: methanol:water solvent solution (1:2:0.8 by volume) for $12 \mathrm{~h}$. Because lipid extraction can cause a fractionation in $\delta^{15} \mathrm{~N}$ (Sotiropoulos et al. 2004), $\delta^{15} \mathrm{~N}$ analysis was conducted on untreated samples. Lipids were not removed from other species as these had C:N ratios lower than 3.5, and no lipid removal or correction for lipid content is needed in these cases (Post et al. 2007).

Samples were dried to a constant weight at $60^{\circ} \mathrm{C}$, homogenized into a fine powder with a mortar and pestle, and $\delta^{13} \mathrm{C}$ and $\delta^{15} \mathrm{~N}$ were measured with an Isoprime mass spectrometer coupled with an element analyser. Results are expressed as per mille (\%o) deviations from the standards, as defined by the equation: $\delta^{13} \mathrm{C}$ or $\delta^{15} \mathrm{~N}=\left[\left(\mathrm{R}_{\text {sample }} / \mathrm{R}_{\text {reference }}\right)-1\right] \times 10^{3}$, where $\mathrm{R}={ }^{13} \mathrm{C} /{ }^{12} \mathrm{C}$ for carbon and ${ }^{15} \mathrm{~N} /{ }^{14} \mathrm{~N}$ for nitrogen. Secondary standards were Australian National University (ANU) cane sucrose for $\delta^{13} \mathrm{C}$ and IAEA-305A for $\delta^{15} \mathrm{~N}$, which were calibrated against PD Belemnite for $\delta^{13} \mathrm{C}$ and ambient air for $\delta^{15} \mathrm{~N}$. Duplicates were run every 12th sample and 2 standards were also run after every 12 samples. Results had a precision (1 SD) of $\pm 0.1 \%$ for both $\delta^{13} \mathrm{C}$ and $\delta^{15} \mathrm{~N}$, calculated from the standards.

\section{Data analysis}

Effect of sex, size and site of collection on sevengill $\delta^{13} \mathrm{C}$ and $\delta^{15} \mathrm{~N}$

Classification and regression tree analysis (CART) (De'ath \& Fabricius 2000) was used to identify the effects of site of collection, sex, maturity and animal size on sevengill $\delta^{13} \mathrm{C}$ and $\delta^{15} \mathrm{~N}$. Season and year of sampling was also included in the models, although samples were collected in the 2 years and all 4 seasons (austral summer of 2006/2007 to summer 2008/ 2009) only from animals from the Derwent Estuary and Norfolk Bay. Hence, if identified by the CART as important factors affecting sevengill $\delta^{13} \mathrm{C}$ and/or $\delta^{15} \mathrm{~N}$, year of sampling or season would only have an effect on animals from these 2 sites. CART analysis is a non-parametric test that deals well with unbalanced designs (De'ath \& Fabricius 2000), and so it is appropriate for use on this type of data. The most complex trees were further analysed to determine if there could be an effect of season or year of sampling for animals from these 2 coastal sites. In the analyses, females were considered mature if larger than 220 cm TL (Ebert 1989, Lucifora et al. 2005). Models were run for each element separately, using the TREES package on S-PLUS $2000^{\circledR}$ (MathSoft). The size of the tree was selected by 10 -fold crossvalidation, and the 1-SE tree considered the final tree model. Differences in $\delta^{13} \mathrm{C}$ and/or $\delta^{15} \mathrm{~N}$ between sites were interpreted as resulting from low connectivity between the respective areas.

\section{Seasonal use of coastal habitats}

An array of 74 acoustic receivers (VR2 receivers, VEMCO) was deployed from December 2007 to June 2009, covering the Derwent Estuary and Norfolk Bay areas. The array was set up as single curtains and gates so that sharks could be detected when moving across and between entrances and choke points in these areas (see Barnett et al. 2011 for detailed explanation of acoustic array design). In July 2009, most of the receivers were removed, but a line of receivers covering the entrance to the Derwent Estuary and one covering the entrance to Norfolk Bay remained in the water until June 2010. During this time, it was not possible to obtain daily presence data inside the study area, but information was used to determine the time period tagged individuals were present in the vicinity of these areas.

Sevengills captured in the 2 areas were internally tagged with acoustic-coded V16 transmitters (90 mm length, $15 \mathrm{~mm} \varnothing)$ with battery lives $>2 \mathrm{yr}(\mathrm{n}=9)$ or $>5$ yr $(\mathrm{n}=34)$ (see Barnett et al. 2011 for tag attachment details). Sharks were tagged during 2 periods. In the first year, 33 sharks were tagged between December 2007 and March 2008 (13 in the Derwent Estuary, 20 in Norfolk Bay; 24 females, 9 males). An additional 10 sharks, 5 for each location, were tagged 
between 17 October and 19 November 2008, making a total of 43 sharks tagged. Tracking data are visually presented in a timeline to show residency patterns and the time spent in the study areas.

Detailed analysis of sevengills and their prey

Stomach samples from sevengill sharks captured in the Derwent Estuary $(\mathrm{n}=49)$ and Norfolk Bay $(\mathrm{n}=$ 129) between December 2006 and February 2009 were collected by stomach flushing. Animal capture and handling procedures are described in Barnett et al. (2010d). Frequency of occurrence $(\% \mathrm{~F})$, percentage of numerical importance $(\% \mathrm{~N})$, percentage of weight (\%W) (Hyslop 1980) and percent index of relative importance (\%IRI) (Cortés 1997) metrics were determined.

For each site, stable isotope values of sevengills were corrected for trophic fractionation and superimposed to their known prey to visually identify any intraspecific differences in diet and any possible trophic relationships (Phillips \& Gregg 2003). Fractionation values of $0.8 \%$ for $\delta^{13} \mathrm{C}$ and $2.4 \%$ for $\delta^{15} \mathrm{~N}$ were used as appropriate for non-lipid extracted muscle tissue of large slow growing elasmobranchs that feed on high protein diet (Hussey et al. 2010). This was done for each individual sevengill separately. Quantitative mixing models were not used because of the poor source geometry of mixing models, coupled with the relatively large number of prey species consumed in each area (Barnett et al. 2010b). Moreover the relative uncertainty of $\delta^{13} \mathrm{C}$ and $\delta^{15} \mathrm{~N}$ trophic fractionation for elasmobranchs means that mixing models will not lead to conclusive results if used to determine the diet composition (Phillips \& Gregg 2003, Bond \& Diamond 2011, Ward et al. 2011). Also, sevengills seasonally move out of these coastal habitats (Barnett et al. 2011), and this coupled with the relatively slow turnover rate of elasmobranch muscle (MacNeil et al. 2006) means that mus- cle isotope composition will not fully equilibrate with local sources and will not accurately reflect the diet in these habitats. Nevertheless, at least for males, which arrive almost simultaneously in the sampled foraging grounds and annually spend a large proportion of their time in the area (Barnett et al. 2011), the analysis of their stable isotope values should give some information on their main diet sources and on intrapopulation differences in diet. The use of tissue with a faster turnover time such as liver would have led to more precise results regarding sevengill diet in these habitats (MacNeil et al. 2006, Logan \& Lutcavage 2010), but in the present study sharks were not killed.

\section{RESULTS}

\section{Effect of sex, size and site of collection on sevengill $\delta^{13} \mathrm{C}$ and $\delta^{15} \mathrm{~N}$}

In total, $\delta^{13} \mathrm{C}$ and $\delta^{15} \mathrm{~N}$ of 146 sevengill individuals ranging from 83 to $270 \mathrm{~cm}$ TL were analysed (Table 1). Carbon isotope composition ranged from -19.0 to $-13.0 \%$ and $\delta^{15} \mathrm{~N}$ from 13.4 to $17.9 \%$, and animals from different sites had different $\delta^{13} \mathrm{C}$ and $\delta^{15} \mathrm{~N}$ (Table 1) .

For $\delta^{13} \mathrm{C}$, the CART model (explaining $40 \%$ of the variability) indicates that sevengill $\delta^{13} \mathrm{C}$ depends primarily on site of collection, as animals from the Maatsuyker Islands, Shelf, Pedra Branca and Storm Bay had on average lower $\delta^{13} \mathrm{C}$ than animals from the inshore sites of the Derwent Estuary and Norfolk Bay (Fig. 2a). For animals from the inshore sites (Derwent Estuary and Norfolk Bay), a second split separated individuals based on sex, with females having higher $\delta^{13} \mathrm{C}$ than males. Among these females, animals collected in autumn had higher $\delta^{13} \mathrm{C}$ values than animals collected between winter and summer (Fig. 2a). There was no effect of size or maturity on sevengill $\delta^{13} \mathrm{C}$, as neither of these variables was responsible for

Table 1. Notorynchus cepedianus. Number of sevengill sharks collected at each site, including number of males and females $(\mathrm{m} / \mathrm{f})$, size range ( $\mathrm{TL}$, in $5 \mathrm{~cm}$ size classes), $\delta^{13} \mathrm{C}$ and $\delta^{15} \mathrm{~N}$ values and bulk $\mathrm{C}: \mathrm{N}$ ratio (mean $\left.\pm \mathrm{SD}\right)$

\begin{tabular}{|lccccc|}
\hline Site & $\mathrm{n}(\mathrm{m} / \mathrm{f})$ & Size range $(\mathrm{cm})$ & $\delta^{13} \mathrm{C}(\%)$ & $\delta^{15} \mathrm{~N}(\%)$ & $\mathrm{C}: \mathrm{N}$ ratio \\
\hline Derwent Estuary & $59(11 / 48)$ & $150-270$ & $-16.6 \pm 1.0$ & $16.3 \pm 0.5$ & $2.9 \pm 0.3$ \\
Norfolk Bay & $63(13 / 50)$ & $120-270$ & $-16.4 \pm 1.3$ & $15.9 \pm 0.9$ & $2.9 \pm 0.3$ \\
Storm Bay & $5(1 / 4)$ & $120-165$ & $-17.1 \pm 0.5$ & $15.5 \pm 0.5$ & $2.8 \pm 0.1$ \\
Maatsuyker Islands & $4(4 / 0)$ & $165-225$ & $-17.6 \pm 0.2$ & $16.2 \pm 0.3$ & $2.5 \pm 0.2$ \\
Pedra Branca & $4(2 / 2)$ & $85-225$ & $-17.7 \pm 0.5$ & $14.8 \pm 0.5$ & $2.5 \pm 0.1$ \\
Shelf & $11(6 / 5)$ & $80-210$ & $-17.7 \pm 0.5$ & $14.6 \pm 0.5$ & $3.3 \pm 0.1$ \\
\hline
\end{tabular}




\section{a $\delta^{13} \mathrm{C}$}

Site: Maat, Shelf, PB, SB Der, NFB

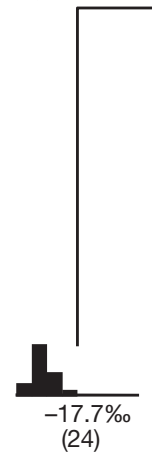

(24)
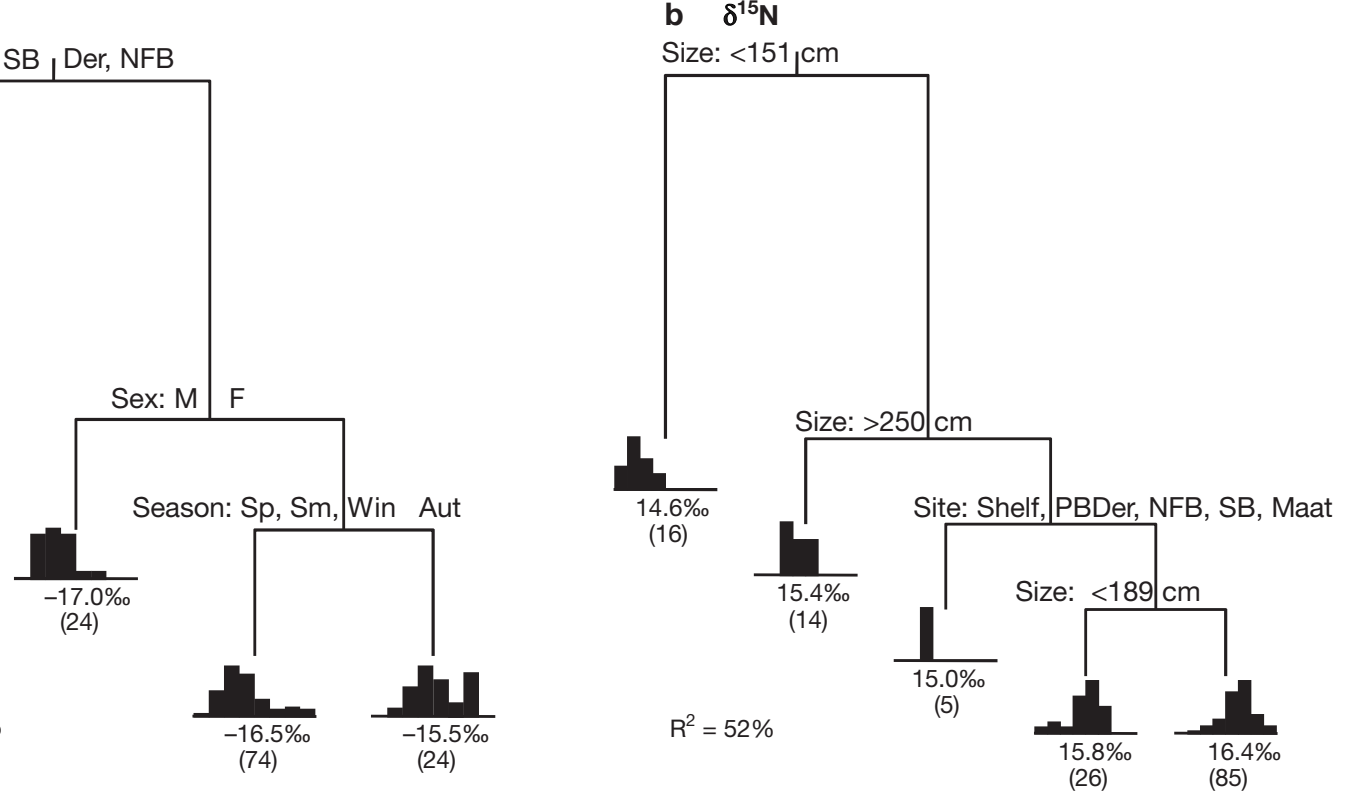

Fig. 2. Notorynchus cepedianus. Classification and regression tree analyses of sevengill (a) $\delta^{13} \mathrm{C}$ and (b) $\delta^{15} \mathrm{~N}$ samples based on site of collection, sex, maturity and size. Histograms of distribution of $\delta^{13} \mathrm{C} / \delta^{15} \mathrm{~N}$ are presented below the terminal nodes and mean $\delta^{13} \mathrm{C} / \delta^{15} \mathrm{~N}$ and sample size (in parentheses) for each group are also indicated. Range in histograms corresponds to -19 to $-13 \%$ for $\delta^{13} \mathrm{C}$ and 13 to $18 \%$ for $\delta^{15} \mathrm{~N}$. Der = Derwent Estuary; Maat = Maatsuyker Islands; NFB = Norfolk Bay; PB = Pedra Branca; SB = Storm Bay

a branch separation in the CART (Fig. 2a). Furthermore, exploration of more complex trees did not show year of sampling as an important factor influencing sevengill $\delta^{13} \mathrm{C}$ for animals from the Derwent Estuary and Norfolk Bay, meaning that for each season, sevengill $\delta^{13} \mathrm{C}$ did not differ between years.

Sevengill $\delta^{15} \mathrm{~N}$ depended primarily on animal size, with animals smaller than $151 \mathrm{~cm}$ TL having in average lower $\delta^{15} \mathrm{~N}$ than larger animals (Fig. 2b). For individuals larger than $150 \mathrm{~cm}$ TL, a second split again separated individuals by size, as animals larger than $250 \mathrm{~cm}$ TL had lower $\delta^{15} \mathrm{~N}$ than those smaller than $250 \mathrm{~cm}$ TL (Fig. 2b). Note that $>250 \mathrm{~cm}$ TL individuals were only captured in the Derwent Estuary and Norfolk Bay, and were all females. For animals of 151 to $250 \mathrm{~cm} \mathrm{TL}$, i.e. most individuals, $\delta^{15} \mathrm{~N}$ depended mostly on site of collection, as individuals from the offshore sites of Shelf and Pedra Branca had lower $\delta^{15} \mathrm{~N}$ than individuals from the Derwent Estuary, Norfolk Bay, Storm Bay and the Maatsuykers (Fig. 2b). For individuals from the Maatsuykers and from the inshore sites Derwent Estuary, Norfolk Bay and Storm Bay, $\delta^{15} \mathrm{~N}$ increased with size, and the division that minimises the sum of squares between groups was at around $189 \mathrm{~cm}$ TL (Fig. 2b). So, overall, $\delta^{15} \mathrm{~N}$ seems to increase with size until animals are $\sim 250 \mathrm{~cm}$ $\mathrm{TL}$, but individuals larger than $250 \mathrm{~cm}$ TL had $\delta^{15} \mathrm{~N}$ values lower than the smaller $(151-250 \mathrm{~cm} \mathrm{TL})$ animals. Taken together, the effects of animal size and site of collection explains $52 \%$ of the total variability in $\delta^{15} \mathrm{~N}$, and there was no effect of sex, maturity, season or year of sampling on sevengill $\delta^{15} \mathrm{~N}$ (Fig. 2b). Also, exploration of more complex trees did not show year of sampling or season as important factors influencing sevengill $\delta^{15} \mathrm{~N}$ for animals from the coastal areas Derwent Estuary and Norfolk Bay.

For sevengills smaller than $250 \mathrm{~cm}$ TL collected in the inshore habitats (Derwent Estuary, Norfolk Bay and Storm Bay), there was a linear relationship between size and $\delta^{15} \mathrm{~N}$ (Regression: $\delta^{15} \mathrm{~N}=13.762+$ $0.012 \times$ size $[\mathrm{cm}], \mathrm{R}^{2}=0.35, F_{1,103}=56.051, \mathrm{p}<0.0001$; Fig. 3). The largest difference in $\delta^{15} \mathrm{~N}$ between animals from this group was $3.6 \%$, between 2 animals from Norfolk Bay (145 and $236 \mathrm{~cm}$ TL). There was no relationship between size and $\delta^{15} \mathrm{~N}$ for animals collected in the Shelf $(p=0.4196)$ or Pedra Branca $(p=$ $0.1677)$, despite the wide size ranges of animals captured at both sites ( 86 to $210 \mathrm{~cm}$ TL in the Shelf and 83 to 226 cm TL in Pedra Branca) (see Fig. 3).

\section{Detailed analysis of data from Derwent Estuary and Norfolk Bay}

Seasonal use of coastal habitats

Sevengills showed seasonality and site fidelity in the use of the coastal habitats of southeast Tasmania 


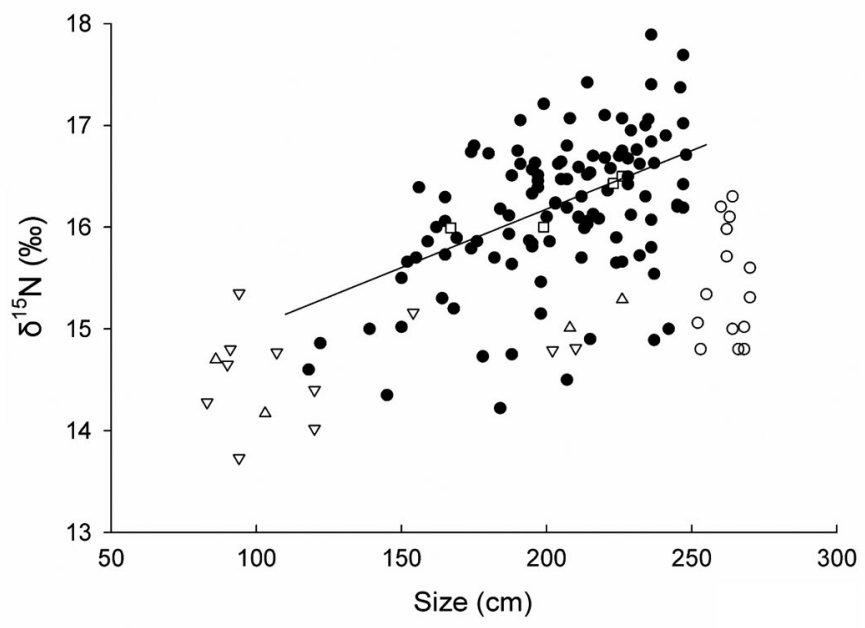

Fig. 3. Notorynchus cepedianus. Relationship between sevengill size (TL in $\mathrm{cm}$ ) and $\delta^{15} \mathrm{~N}$ for $(\bullet)$ animals smaller than $250 \mathrm{~cm}$ TL collected in the inshore areas Derwent Estuary, Norfolk Bay and Storm Bay; (O) animals larger than $250 \mathrm{~cm}$ TL from the same sites; $(\square)$ animals from Maatsuyker; $(\Delta)$ animals from Pedra Branca; $(\nabla)$ animals from the Shelf. Line represents the significant relationship between size and $\delta^{15} \mathrm{~N}$ for animals collected in the inshore sites (Derwent Estuary, Norfolk Bay and Storm Bay; $\delta^{15} \mathrm{~N}=13.762+0.012 \times$ size, $\mathrm{R}^{2}=0.35$ ). No significant relationship between animal size and $\delta^{15} \mathrm{~N}$ was found for any of the remaining groups
(Fig. 4). The general pattern was for sharks to leave the coastal areas over winter and return the following spring or summer (Fig. 4). Sex-specific variations on this pattern were evident, as females had longer periods of residency in these areas and some were still detected during winter, while all tagged males but one left the area for winter (Fig. 4). Also, females that left generally returned in spring, whereas males arrived later in summer (Fig. 4). Nine (3 males and 6 females) of the 32 individuals tagged in the first year returned to the coastal areas in 2 consecutive years, after being absent for the colder periods (Fig. 4). Eight out of the 24 females that left after the first autumn did not return the following year, but one of them returned 2 summers later, in February 2010 (Fig. 4).

\section{Stomach content analysis}

A total of 178 stomachs containing food were analysed, 49 from the Derwent Estuary and 129 from Norfolk Bay. Sharks, batoids, teleosts and mammals were important at both sites (Table 2), but there were some differences between sites. Teleosts were the

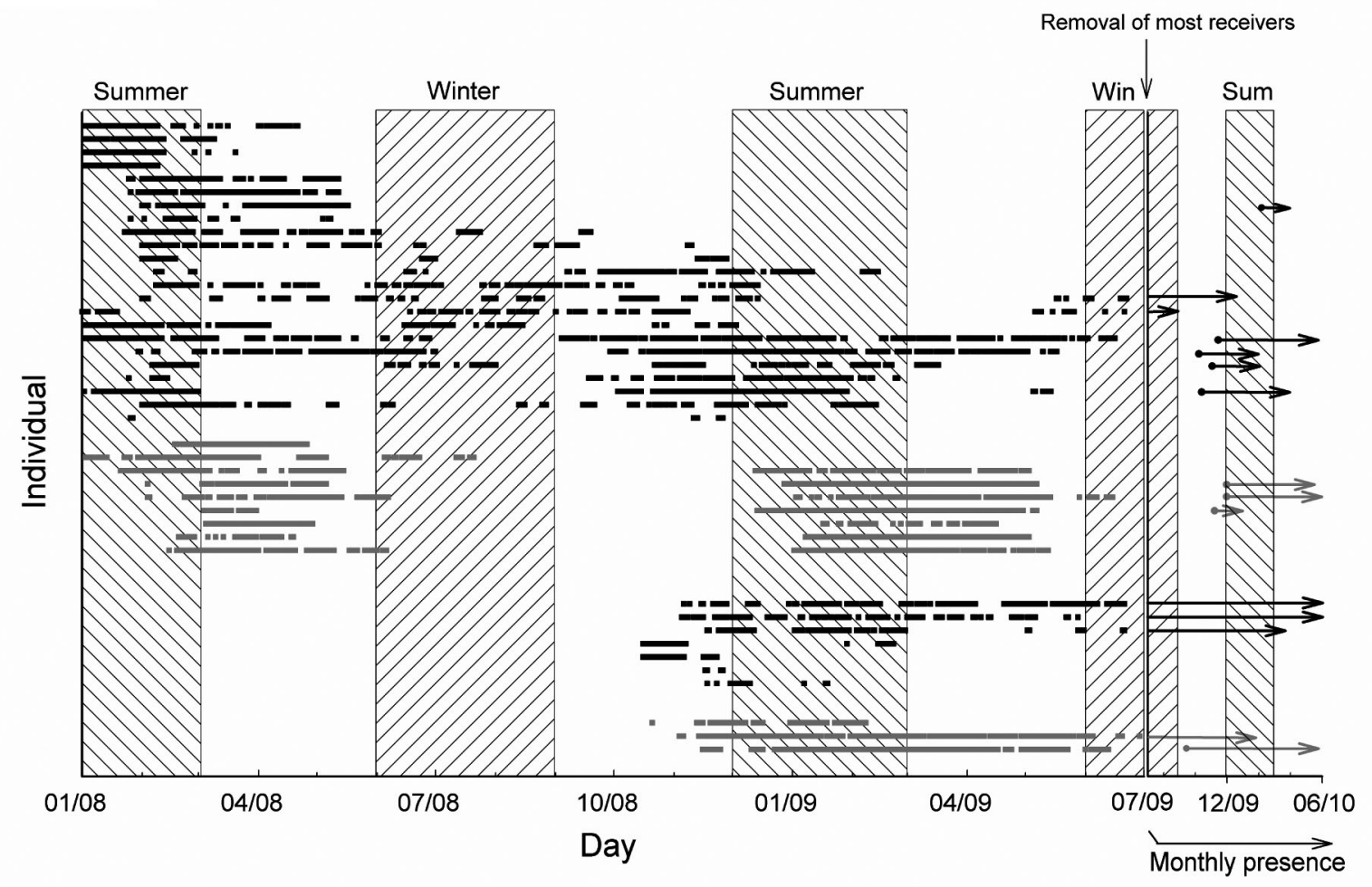

Fig. 4. Notorynchus cepedianus. Timelines showing when each individual shark was detected in the coastal area of southeast Tasmania from January 2008 to July 2010. Females are in black and males in grey. For each individual, the first point marked on the graph corresponds to the tagging day, with the exception of sharks that were tagged before January 2008. Until July 2009, daily detections are shown; from July 2009 to July 2010, only the curtains of receivers at the entrance of the Derwent Estuary and Norfolk Bay were deployed, so animals could be inside the coastal area but not be detected. Arrows represent the time period sharks were detected by these curtains. This is an update of Fig. 4 in Barnett et al. (2011) 
main prey at the Derwent Estuary, occurring in $49.0 \%$ of stomachs analysed, followed by batoids $(30.6 \%)$ and sharks $(28.6 \%)$, while mammals (mainly seals) occurred in $12.2 \%$ of stomachs (Table 2). At a species level, southern shortfin eel Anguilla australis occurred most frequently $(14.3 \%)$, followed by white-spotted spurdog Squalus acanthias (12.2\%), Australian sardine Sardinops neopilchardus (12.2\%) and gummy shark Mustelus antarcticus (10.2\%). Australian fur seal Arctocephalus pusillus doriferus $(8.2 \%)$, southern eagle ray Myliobatis australis, banded stingaree Urolophus cruciatus and elephantfish Callorhinchus milii were also important (8.2\% occurrence in each case; Table 2).

In Norfolk Bay, sharks were the most important prey $(38.6 \%)$, followed by batoids and teleosts $(27.6 \%$ in both cases), and mammals occurred in $23.6 \%$ the stomachs containing food (Table 2). At a species level, gummy shark was the most important prey ( $25.2 \%$ occurrence), followed by Australian fur seal $(14.2 \%)$, Melbourne skate Spiniraja whitleyi $(10.2 \%)$, spurdog $(8.7 \%)$ and southern eagle ray $(7.9 \%)$. It was not possible to analyse differences in diet between sexes or seasons for either site because when the data are separated into these categories, the sample sizes become too small. A more detailed analysis of sevengill stomach content data is presented in Barnett et al. (2010b).

\section{Stable isotope analysis}

Muscle tissue of 59 sevengills from the Derwent Estuary (11 males, 48 females) and 63 from Norfolk Bay (13 males, 50 females) was analysed for stable isotopes, along with their main prey. For both sites, the stable isotope composition of sevengill individuals captured at the same time as prey (i.e. between

Table 2. Main prey species present in the stomach contents of sevengill sharks in the Derwent Estuary $(\mathrm{n}=49)$ and Norfolk Bay $(n=129)$, with indication of frequency of occurrence $(\% \mathrm{~F})$, percentage of numerical importance $(\% \mathrm{~N})$, percentage of weight $(\% \mathrm{~W})$ and the percentage index of relative importance (\%IRI). Only species with \%IRI $>1 \%$ and species for which stable isotope results are available are presented

\begin{tabular}{|c|c|c|c|c|c|c|c|c|c|}
\hline \multirow[t]{2}{*}{ Species } & \multirow{2}{*}{ Common name } & \multicolumn{4}{|c|}{ Derwent Estuary } & \multicolumn{4}{|c|}{ Norfolk Bay } \\
\hline & & $\% \mathrm{~F}$ & $\% \mathrm{~N}$ & $\% W$ & IRI & $\% \mathrm{~F}$ & $\% \mathrm{~N}$ & $\% \mathrm{~W}$ & $\%$ IRI \\
\hline Mammals & & 12.2 & 6.0 & 11.7 & 3.2 & 23.6 & 15.1 & 42.6 & 24.3 \\
\hline Arctocephalus pusillus doriferus & Australian fur seal & 8.2 & 4.0 & 4.8 & 4.6 & 14.2 & 9.1 & 35.3 & 28.8 \\
\hline Tursiops truncatus & Bottlenosed dolphin & - & - & - & & 4.7 & 3.0 & 6.4 & 2.0 \\
\hline Sharks & & 28.6 & 14.7 & 35.4 & 21.5 & 38.6 & 28.8 & 31.1 & 41.3 \\
\hline Mustelus antarcticus & Gummy shark & 10.2 & 5.0 & 11.9 & 11.0 & 25.2 & 17.2 & 17.6 & 40.1 \\
\hline Galeorhinus galeus & School shark & - & - & - & - & 2.4 & 1.5 & 1.4 & 0.3 \\
\hline Squalus acanthias & Whitespotted spurdog & 12.2 & 6.0 & 6.9 & 10.1 & 8.7 & 5.6 & 1.8 & 2.9 \\
\hline Notorynchus cepedianus & Broadnose sevengill shark & 2.0 & 1.0 & 13.3 & 1.8 & 2.4 & 1.5 & 7.2 & 1.0 \\
\hline Cephaloscyllium laticeps & Draughtboard shark & 2.0 & 1.0 & 1.3 & 0.3 & 0.8 & 0.5 & 0.9 & 0.1 \\
\hline Batoids & & 30.6 & 15.7 & 18.3 & 15.6 & 27.6 & 22.7 & 19.9 & 21.0 \\
\hline Myliobatis australis & Southern eagle ray & 8.2 & 4.0 & 13.4 & 9.1 & 7.9 & 5.6 & 7.8 & 4.8 \\
\hline Spiniraja whitleyi & Melbourne skate & 2.0 & 1.0 & $<0.1$ & 0.1 & 10.2 & 7.1 & 9.5 & 7.7 \\
\hline Dentiraja lemprieri & Thornback skate & 4.1 & 2.0 & $<0.1$ & 0.5 & 1.6 & 1.0 & 0.8 & 0.1 \\
\hline Dipturus confusus & Longnose skate & 2.0 & 1.0 & 1.7 & 0.3 & - & - & - & - \\
\hline Narcine tasmaniensis & Tasmanian numbfish & - & - & - & - & 0.8 & 1.0 & 0.5 & 0.1 \\
\hline Urolophus cruciatus & Banded stingaree & 8.2 & 4.0 & 2.5 & 3.4 & 6.3 & 5.6 & 1.7 & 2.1 \\
\hline Chimaeras & & 8.2 & 4.0 & 4.5 & 1.0 & 2.4 & 1.5 & 0.8 & 0.1 \\
\hline Callorhinchus milii & Elephantfish & 8.2 & 4.0 & 4.5 & 4.5 & 2.4 & 1.5 & 0.8 & 0.3 \\
\hline Cephalopods & & 2.0 & 1.0 & 0.6 & 0.2 & 7.1 & 5.6 & 0.3 & 0.7 \\
\hline Nototodarus gouldi & Gould's squid & 2.0 & 1.0 & 0.6 & 0.2 & 4.7 & 3.0 & 0.3 & 0.7 \\
\hline Teleosts & & 49.0 & 50 & 29.4 & 58.5 & 27.6 & 20.2 & 5.3 & 12.6 \\
\hline Arripis trutta & Australian salmon & 8.2 & 4.0 & 4.0 & 4.2 & 0.8 & 0.5 & 0.4 & 0.0 \\
\hline Sardinops neopilchardus & Australian sardine & 12.2 & 6.0 & 1.1 & 5.5 & - & - & - & - \\
\hline Platycephalus bassensis & Sand flathead & 2.0 & 1.0 & 0.1 & 0.1 & 1.6 & 1.0 & 0.1 & 0.1 \\
\hline Salmo trutta & Brown trout & 0.8 & 2.0 & $<0.1$ & 0.1 & - & - & - & - \\
\hline Aldrichetta forsteri & Yellow-eye mullet & 6.1 & 5.0 & 4.9 & 3.9 & - & - & - & - \\
\hline Latridopsis forsteri & Bastard trumpeter & 6.1 & 4.0 & 4.9 & 3.5 & 1.6 & 1.0 & 0.1 & 0.1 \\
\hline Anguilla australis & Southern shortfin eel & 14.3 & 16 & 7.2 & 21.2 & - & - & - & \\
\hline Conger verreauxi & Southern conger eel & - & - & - & & 3.1 & 2.0 & 0.4 & 0.3 \\
\hline
\end{tabular}


November 2008 and February 2009) was not different to that of sevengills captured at other times (Fig. 5). The prey species analysed reflected the most abundant species in each site, and the most important prey found in sevengill stomachs. The only prey missing are the shortfin eel and the Australian sardine from the Derwent Estuary, which could not be caught with any of the used gears.

In the Derwent Estuary, sevengill prey ranged in $\delta^{13} \mathrm{C}$ from $-19.2 \%$ for brown trout Salmo trutta to $-15.5 \%$ for eagle ray (Table 3, Fig. 5). For $\delta^{15} \mathrm{~N}$, eagle ray had the lowest values (mean $=12.0 \%$ ), and conger eel Conger verreauxi and the fur seal the highest $(16.6 \%)$. Sevengills had a wide range in $\delta^{13} \mathrm{C}$, ranging from -19.0 to $-13.9 \%$ and encompassing the entire range in prey $\delta^{13} \mathrm{C}$ (Fig. 5). Nitrogen isotope composition varied from 15.0 to $17.4 \%$. In comparison with some of the most important species in their diet at this site (Table 2), most (38) sevengill individuals had lower $\delta^{15} \mathrm{~N}$ than fur seal, and most were only marginally higher than spurdog and gummy shark (Fig. 5). After correction for trophic fractionation, $\delta^{15} \mathrm{~N}$ values for most individual sevengills were lower than for several of the dominant species in their diet like spurdogs and gummy sharks (Table 2), and lower even than for most teleosts (Fig. 5). For 7 individuals, corrected isotopic composition fell close to southern eagle ray (the species most separated from all others) or between the eagle ray and all other fish species, and outside the polygon delimited by all other prey (Fig. 5).

In Norfolk Bay, the prey polygon was relatively narrow. Sevengill prey ranged in $\delta^{13} \mathrm{C}$ from $-18.3 \%$ for spurdog to $-14.0 \%$ for eagle ray, and $\delta^{15} \mathrm{~N}$ ranged from $9.7 \%$ for eagle ray to $15.2 \%$ for school shark Galeorhinus galeus (Table 3, Fig. 5). As in the Derwent Estuary, sevengills from Norfolk Bay also had a wide range in $\delta^{15} \mathrm{~N}$ (14.4 to $17.9 \%$ ) and $\delta^{13} \mathrm{C}$ (-18.1 to $-13.0 \%$; Fig. 5). Most (45) individuals had $\delta^{13} \mathrm{C}$ between $-18.1 \%$ and $-16.3 \%$ while 11 $(17.5 \%)$ seemed to form a group with higher $\delta^{13} \mathrm{C}$ $\left(-14.9\right.$ to $-13.0 \%$ ) and lower and very close $\delta^{15} \mathrm{~N}$ (14.2 to $15.1 \%$; Fig. 5). This latter group was composed exclusively of females. For these females, corrected $\delta^{13} \mathrm{C}$ values fell between eagle ray and all other prey species, but corrected $\delta^{15} \mathrm{~N}$ fell above

Table 3. Size range, stable isotope composition and C:N ratio (mean $\pm \mathrm{SE}$ ) of sevengill main prey species collected in the Derwent Estuary and Norfolk Bay. Sizes are TL for sharks and fish and disc width for rays and stingarees, in $5 \mathrm{~cm}$ size classes. ${ }^{*}$ Species for which samples were delipidated before $\delta^{13} \mathrm{C}$ analysis

\begin{tabular}{|c|c|c|c|c|c|c|}
\hline Species & Common name & $n$ & Size $(\mathrm{cm})$ & $\begin{array}{c}\delta^{13} \mathrm{C} \\
(\% \circ)\end{array}$ & $\begin{array}{c}\delta^{15} \mathrm{~N} \\
(\% \circ)\end{array}$ & $\mathrm{C}: \mathrm{N}$ ratio \\
\hline \multicolumn{7}{|l|}{ Derwent Estuary } \\
\hline Arctocephalus pusillus doriferus* & Australian fur seal & 3 & $\sim 200$ & $-18.3 \pm 0.2$ & $16.6 \pm 0.1$ & $4.2 \pm 0.1$ \\
\hline Squalus acanthias & Whitespotted spurdog & 13 & $65-85$ & $-17.9 \pm 0.2$ & $15.3 \pm 0.1$ & $3.0 \pm 0.1$ \\
\hline Mustelus antarcticus & Gummy shark & 20 & $85-110$ & $-16.1 \pm 0.4$ & $14.7 \pm 0.3$ & $2.9 \pm 0.1$ \\
\hline Myliobatis australis & Southern eagle ray & 4 & $140-150$ & $-15.5 \pm 0.4$ & $12.0 \pm 0.4$ & $3.1 \pm 0.1$ \\
\hline Dentiraja lemprieri & Thornback skate & 3 & $30-35$ & $-18.2 \pm 0.2$ & $15.6 \pm 0.2$ & $2.7 \pm 0.1$ \\
\hline Dipturus confusus & Longnose skate & 2 & $30-35$ & $-16.5 \pm 0.2$ & $15.3 \pm 0.2$ & $3.1 \pm 0.1$ \\
\hline Spiniraja whitleyi & Melbourne skate & 8 & $115-135$ & $-17.4 \pm 0.2$ & $15.4 \pm 0.3$ & $3.1 \pm 0.1$ \\
\hline Urolophus cruciatus & Banded stingaree & 5 & $18-20$ & $-17.3 \pm 0.2$ & $15.0 \pm 0.2$ & $2.9 \pm 0.0$ \\
\hline Narcine tasmaniensis & Tasmanian numbfish & 5 & 15 & $-16.8 \pm 0.3$ & $14.6 \pm 0.2$ & $3.0 \pm 0.0$ \\
\hline Callorhinchus milii & Elephantfish & 8 & $75-90$ & $-17.4 \pm 0.2$ & $13.5 \pm 0.3$ & $2.8 \pm 0.2$ \\
\hline Conger verreauxi* & Southern conger eel & 6 & $150-160$ & $-17.7 \pm 0.1$ & $16.6 \pm 0.4$ & $4.2 \pm 0.0$ \\
\hline Arripis trutta & Australian salmon & 6 & $30-40$ & $-17.7 \pm 0.2$ & $15.0 \pm 0.2$ & $3.2 \pm 0.0$ \\
\hline Salmo trutta* & Brown trout & 6 & $35-55$ & $-19.2 \pm 0.3$ & $14.9 \pm 0.3$ & $4.2 \pm 0.1$ \\
\hline Platycephalus bassensis & Sand flathead & 6 & $30-35$ & $-17.7 \pm 0.2$ & $14.4 \pm 0.2$ & $3.5 \pm 0.2$ \\
\hline Aldrichetta forsteri* & Yellow-eye mullet & 6 & $25-35$ & $-18.8 \pm 0.3$ & $14.1 \pm 0.3$ & $4.0 \pm 0.0$ \\
\hline Nototodarus gouldi & Gould's squid & 6 & $30-35$ & $-18.0 \pm 0.2$ & $14.7 \pm 0.3$ & $3.1 \pm 0.0$ \\
\hline \multicolumn{7}{|l|}{ Norfolk Bay } \\
\hline Galeorhinus galeus & School shark & 11 & $75-170$ & $-17.6 \pm 0.2$ & $15.2 \pm 0.1$ & $2.8 \pm 0.1$ \\
\hline Mustelus antarcticus & Gummy shark & 19 & $75-130$ & $-16.8 \pm 0.2$ & $13.2 \pm 0.2$ & $2.9 \pm 0.1$ \\
\hline Squalus acanthias & Whitespotted spurdog & 3 & $60-90$ & $-18.3 \pm 0.2$ & $14.8 \pm 0.2$ & $3.0 \pm 0.1$ \\
\hline Dasyatis brevicaudata & Smooth stingray & 5 & 85-105 & $-17.2 \pm 0.3$ & $12.5 \pm 0.3$ & $2.7 \pm 0.1$ \\
\hline Myliobatis australis & Southern eagle ray & 5 & 140 & $-14.0 \pm 0.2$ & $9.7 \pm 0.2$ & $3.2 \pm 0.1$ \\
\hline Spiniraja whitleyi & Melbourne skate & 5 & 105-135 & $-16.9 \pm 0.2$ & $13.9 \pm 0.4$ & $3.2 \pm 0.1$ \\
\hline Platycephalus bassensis & Sand flathead & 5 & $30-35$ & $-18.0 \pm 0.1$ & $14.0 \pm 0.2$ & $3.3 \pm 0.1$ \\
\hline Nototodarus gouldi & Gould's squid & 6 & $30-40$ & $-17.9 \pm 0.2$ & $14.5 \pm 0.2$ & $3.5 \pm 0.0$ \\
\hline
\end{tabular}




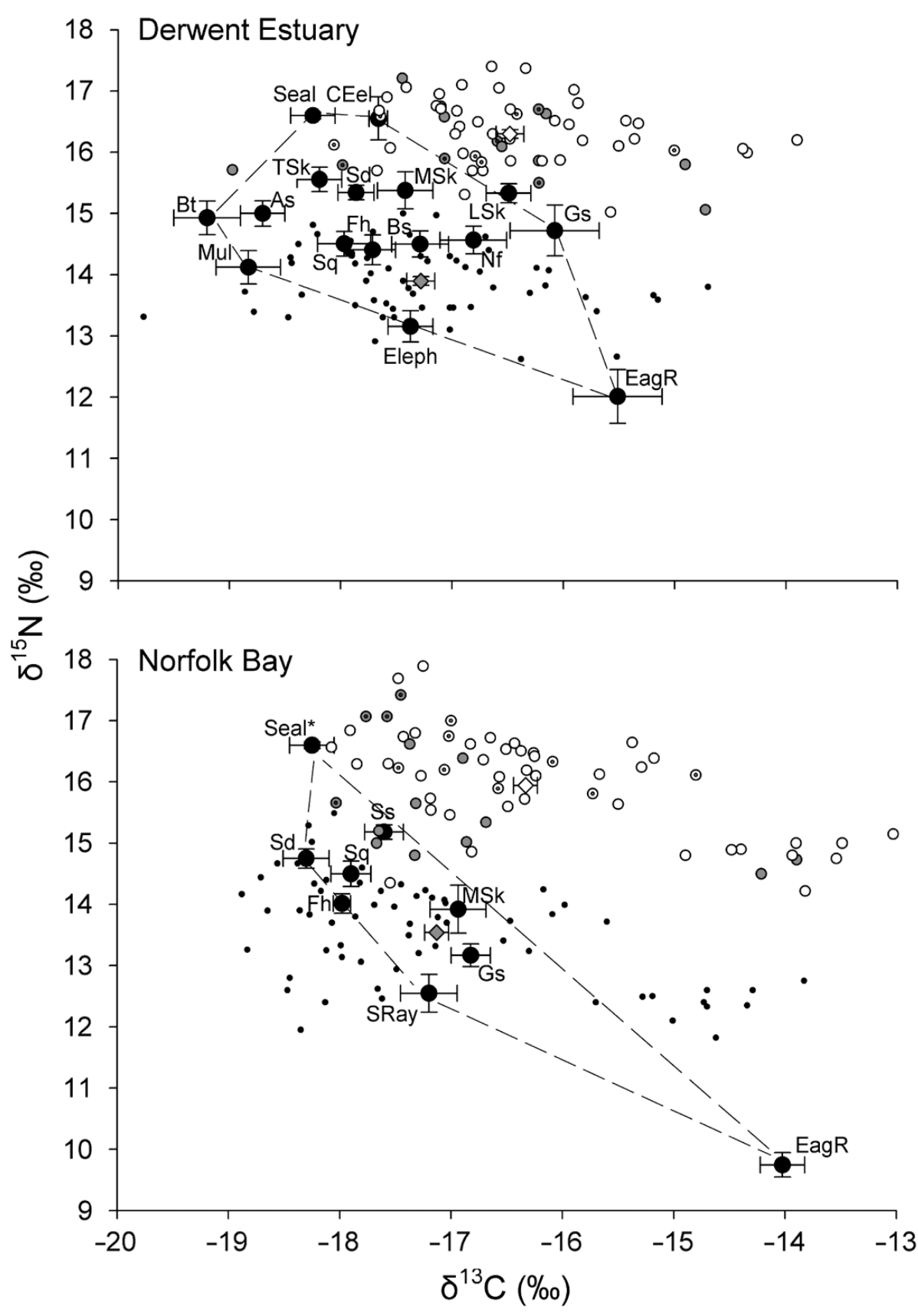

Fig. 5. $\delta^{13} \mathrm{C}$ and $\delta^{15} \mathrm{~N}$ of individual sevengill sharks and their prey in the Derwent Estuary (top) and Norfolk Bay (bottom). Stable isotope values are shown for female ( $\bigcirc$ ) and male (๑) sevengills that were captured during the same season as prey; for female (O) and male (๑) sevengills captured at other times; and for sevengills $(\bullet)$ after correction for trophic fractionation for one trophic level $\left(0.8 \%\right.$ for $\delta^{13} \mathrm{C}$ and $2.4 \%$ for $\left.\delta^{15} \mathrm{~N}\right)$. The diagram also shows mean $( \pm \mathrm{SD})(\diamond)$ and corrected mean $(\diamond) \delta^{13} \mathrm{C}$ and $\delta^{15} \mathrm{~N}$ values for sevengills, and the polygon delimiting sevengill prey in each area. $\mathrm{Bs}=$ banded stingaree; $\mathrm{Bt}=$ brown trout $; \mathrm{CEel}=$ southern conger eel $; \mathrm{Sd}=$ whitespotted spurdog; EagR = southern eagle ray; Eleph = elephantfish; Fh = sand flathead; Gs = gummy shark; LSk = longnose skate; $\mathrm{MSk}=$ Melbourne skate; $\mathrm{Mul}=$ yelloweye mullet; $\mathrm{Nf}=$ Tasmanian numbfish; $\mathrm{Sq}=$ Gould's squid; SRay $=$ smooth stingray; $\mathrm{Ss}=$ school shark; $\mathrm{TSk}=$ thornback skate. ${ }^{*}$ Seal isotopic values from animals from the Derwent Estuary, as no seal samples were available for Norfolk Bay the source polygon (Fig. 5). For the remaining animals, however, and as in Derwent Estuary, in many cases corrected $\delta^{15} \mathrm{~N}$ fell lower than most of their prey (gummy shark, seal, Melbourne skate and spurdog; Table 2), and outside the prey polygon (Fig. 5).

\section{DISCUSSION}

\section{Effect of site of collection on sevengill $\delta^{13} \mathrm{C}$ and $\delta^{15} \mathrm{~N}$}

The differences in $\delta^{13} \mathrm{C}$ and $\delta^{15} \mathrm{~N}$ between animals from inshore and offshore sites imply that most sevengills spent significant amounts of time in the habitats where they were caught (inshore vs. offshore), enough for their tissues to show differences in stable isotope composition between areas. In general, there was an increase in both $\delta^{13} \mathrm{C}$ and $\delta^{15} \mathrm{~N}$ from lower values for animals collected in the offshore sites of Shelf and Pedra Branca, to intermediate values for animals from the more open area of Storm Bay and finally to higher values for sevengills from the coastal habitats of Derwent Estuary and Norfolk Bay (Table 1). The offshore site of the Maatsuyker Islands, however, did not fit this pattern, with animals having high $\delta^{15} \mathrm{~N}$ values, similar to those of individuals from the coastal habitats (Table 1 ). The high $\delta^{15} \mathrm{~N}$ for animals from the Maatsuyker Islands when compared to other offshore areas (Shelf and Pedra Branca) is most likely a result of consumption of seal, as large seal colonies occur in the islands, and all sharks captured at this site had seal in their stomachs (Barnett et al. 2010b). Similarly, seals dominated the diet of sevengills caught in proximity to seal colonies in southern Africa (Ebert 1991).

For the remaining sites, lower $\delta^{15} \mathrm{~N}$ in sevengills captured offshore when compared to those from inshore most likely occurs because the baseline 
$\delta^{15} \mathrm{~N}$ of the offshore food web is lower, and this difference is propagated up the food chains so that animals of similar trophic position have lower $\delta^{15} \mathrm{~N}$ offshore then in inshore areas (Vander Zanden \& Rasmussen 1999, Sherwood \& Rose 2005). Sevengills from the coastal areas also had higher $\delta^{15} \mathrm{~N}$ than other large high trophic level species captured in offshore waters of southeast Australia (Appendix 1). Previous studies also reported $\delta^{15} \mathrm{~N}$ for a range of species in pelagic waters off the southeast Australian continental shelf, and these were consistently lower than the values for the coastal areas considered in the present study (Appendix 2). Differences between inshore and offshore $\delta^{15} \mathrm{~N}$ can be further increased if inshore systems are close to urban areas, a result of the incorporation of sewage and/or agriculture runoff (Costanzo et al. 2003). In accordance, all prey species that occurred in both the Derwent Estuary and Norfolk Bay had higher $\delta^{15} \mathrm{~N}$ in the Derwent Estuary (see Table 3), which is highly polluted from industry and urbanization (Leeming \& Nichols 1998). This difference between inshore and offshore $\delta^{15} \mathrm{~N}$ could also be because the offshore food web is shorter, and this is reflected in the $\delta^{15} \mathrm{~N}$ of top predators, or because sharks feed at a lower trophic level while offshore. This latter hypothesis is however unlikely because sevengills feed at the highest trophic level throughout their distribution (see Barnett et al. 2010b and references therein for a summary of sevengill diet throughout their distribution).

Regarding $\delta^{13} \mathrm{C}$, higher values for animals captured in inshore areas when compared to offshore can be related to inshore versus offshore differences in particulate organic matter $\delta^{13} \mathrm{C}$. High $\delta^{13} \mathrm{C}$ values are generally associated to coastal habitats, as $\delta^{13} \mathrm{C}$ is typically higher in inshore benthic food webs than in offshore plankton-based food webs (Fry et al. 1983, France 1995, Sherwood \& Rose 2005). Kelp and seagrass, producers generally associated to coastal habitats, have higher $\delta^{13} \mathrm{C}$ than planktonic producers (Clementz \& Koch 2001). These differences in $\delta^{13} \mathrm{C}$ propagate up the food web to high trophic level species such as sharks (McMeans et al. 2010, Matich et al. 2011).

\section{Effect of size and sex on sevengill $\delta^{13} \mathrm{C}$ and $\delta^{15} \mathrm{~N}$}

In general, sevengill $\delta^{15} \mathrm{~N}$ increased with size, in agreement with the previously reported increase in trophic level with size (Ebert 2002, Lucifora et al. 2005, Braccini 2008). However, the largest animals $\left(>250 \mathrm{~cm} \mathrm{TL}\right.$ ) had lower $\delta^{15} \mathrm{~N}$ than the smaller size class (189-250 cm TL). This was unexpected, as an increase in size generally coincides with an increase in consumption of higher trophic level prey such as marine mammals and other sharks (Ebert 2002, Lucifora et al. 2005, Braccini 2008). Note that this difference in $\delta^{15} \mathrm{~N}$ between sizes was present despite the fact that $\delta^{15} \mathrm{~N}$ turnover is slow for such large and slow growing animals (MacAvoy et al. 2001, MacNeil et al. 2006). This indicates that these largest animals either feed consistently on lower trophic level prey than smaller individuals, which is not likely due to the known increase in trophic level with size (Ebert 2002, Lucifora et al. 2005, Braccini 2008), or that they spend a large amount of time feeding in a different area, characterized by lower baseline $\delta^{15} \mathrm{~N}$.

Since all $>250 \mathrm{~cm}$ TL animals were females (males do not grow that large; Last \& Stevens 2009), one possibility is that pregnant sharks stay in a different area for the length of their pregnancy or at least for the majority of it, where they give birth. If this is the case, older (and larger) females should have more distinct stable isotope composition because they would have spent proportionately more time in these areas throughout their life. Although in California (Ebert 1989) and Argentina (Lucifora et al. 2005) sevengills use coastal bays as pupping and nursery areas, neonates and juveniles do not use inshore areas as nurseries in Tasmania (Barnett et al. 2010a), and it is not known where pregnant females occur. Sevengill females mature at $220 \mathrm{~cm}$ TL (Ebert 1989, Lucifora et al. 2005), and adults give birth every 2 yr, after a gestation period of 12 mo (Ebert 1989; van Dykhuizen \& Mollet 1992). Shark species with 2 yr reproductive cycles often have 2 yr migration patterns (Compagno et al. 2005), and this could explain the differences in movement pattern among females as well as differences in stable isotope composition between sexes.

\section{Detailed analysis of Sevengills from Derwent Estuary and Norfolk Bay and their prey}

Sevengill sharks are considered to occupy the highest trophic level among shark species, even slightly higher than the white shark Charcharodon charcarias (Cortés 1999). Since $\delta^{15} \mathrm{~N}$ increases with trophic level (DeNiro \& Epstein 1981), within their food web, sevengills should have the highest $\delta^{15} \mathrm{~N}$ of all species. However, for both the Derwent Estuary and Norfolk Bay, sevengills had $\delta^{15} \mathrm{~N}$ values lower than expected for a top predator, and lower than expected based on their known diet at these sites. 
Because of the consumption of high trophic level prey (Table 2) and the possible relationship between prey $\delta^{15} \mathrm{~N}$ and $\Delta \delta^{15} \mathrm{~N}$ (Caut et al. 2008, 2009), it could be argued that these lower than expected values are because sevengill trophic fractionation is lower than the $2.4 \%$ used, based on Hussey et al. (2010). However, the animals considered in Hussey et al. (2010) were fed predominantly teleosts with $\delta^{15} \mathrm{~N}$ between 12 and $16 \%$, values similar to those of prey species analysed here. Conversely, $\Delta \delta^{15} \mathrm{~N}$ could be higher than $2.4 \%$, and similar to that of teleosts (Logan \& Lutcavage 2010). Mean $\Delta \delta^{15} \mathrm{~N}$ found for teleost muscle in published reviews is higher than $2.4 \%$, although with some variability (Vanderklift \& Ponsard 2003: $3.1 \pm$ 0.6\% ( \pm SD); Caut et al. 2009: $3.2 \pm$ $1.4 \%$ ). So, it is possible that sevengill corrected $\delta^{15} \mathrm{~N}$ values could be even lower that those calculated, and lower than most of their prey.

Lower than expected $\delta^{15} \mathrm{~N}$ probably results from these animals not residing permanently in these coastal habitats, as shown by tracking data, which shows that sevengills seasonally move out of the studied areas for winter and that most return next spring/summer. After a change in diet, it takes time for the stable isotope composition of muscle to change and reflect a new diet source. Nitrogen turnover in elasmobranch muscle tissue is slow and can take over 1 yr (MacNeil et al. 2006, Logan \& Lutcavage 2010). Also, the few studies on elasmobranch nitrogen turnover rates have been done in relatively small species (but see Hussey et al. 2010 and Logan \& Lutcavage 2010), so turnover rate is likely to be even slower for the sevengills sampled in this study. So, if sevengills seasonally move between areas with different baseline $\delta^{15} \mathrm{~N}$, their muscle will never reach equilibrium with local sources in each habitat, but will reflect the average diet over a long time period.

Female sevengills also showed, on average, higher $\delta^{13} \mathrm{C}$ than males. This is probably again a result of differing movement patterns between sexes: females stay in the sampled coastal areas for longer periods of time, and this leads to measurable differences in muscle $\delta^{13} \mathrm{C}$. Furthermore, evidence from electronic tagging suggests a seasonal northern migration by males to New South Wales (NSW) (Barnett et al. 2011); $70 \%$ of Notorynchus cepedianus caught in the NSW shark control program are male and catches primarily occur in winter to spring (Reid et al. 2011). In southeast Australia, fish predators (including sharks) north of the Tasman Front $\left(\sim 34^{\circ} \mathrm{S}\right)$ have lower $\delta^{15} \mathrm{~N}$ than those found further south, probably as a result of differences in baseline $\delta^{15} \mathrm{~N}$ (Revill et al. 2009), as particulate organic matter $\delta^{15} \mathrm{~N}$ is lower north of the Tasman Front than in waters further south ( 6 vs. 10\%) (Baird et al. 2008). If males seasonally move above the Tasman Front, then $\delta^{15} \mathrm{~N}$ would reflect the average diet throughout the year, both when in Tasmania and when in NSW, and that would explain the lower than expected $\delta^{15} \mathrm{~N}$ for the animals captured in the Derwent Estuary and Norfolk Bay. It is not known where females go when they leave these areas for the winter. Some animals could move offshore, as for the same taxa offshore $\delta^{15} \mathrm{~N}$ is often lower than inshore $\delta^{15} \mathrm{~N}$ in this area (Appendix 2). Further studies tracking both males and females with PSAT tags across all seasons should be conducted to test this hypothesis.

Because of the seasonal movement out of the studied coastal areas, the similarity in prey $\delta^{13} \mathrm{C}$ and $\delta^{15} \mathrm{~N}$ and the relative uncertainty in $\delta^{13} \mathrm{C}$ and $\delta^{15} \mathrm{~N}$ trophic fractionation, it is not possible to quantitatively determine the importance of the different prey to sevengill diet in the Derwent Estuary or Norfolk Bay. Nevertheless, because sevengills have strong site fidelity, and at least for males, spend a large part of the year in these coastal habitats and return to the sampled foraging area each year (Fig. 4; Barnett et al. 2011), the stable isotope composition of their muscle tissue will reflect the food consumed in these areas to a certain extent (although not 100\%) and should be useful to identify any differences in diet. Hence, at least for males, differences in $\delta^{13} \mathrm{C}$ and $\delta^{15} \mathrm{~N}$ between individuals within the same site can be a result of intrapopulation variability in diet, i.e. that different animals feed differently on the available prey (Bolnick et al. 2003, Post 2003). If males were generalists, then they would present a relatively narrow range in $\delta^{13} \mathrm{C}$ and $\delta^{15} \mathrm{~N}$, as all individuals would be feeding on the same prey in similar proportions (Matthews \& Mazumder 2004), and this was not the case for these 2 coastal sites. A relatively high variability in shark $\delta^{13} \mathrm{C}$ has been reported in other recent studies, and was related to the differential use of pelagic versus benthic resources (McMeans et al. 2010), or to specialisation on different prey by different individuals (Matich et al. 2011).

It can also be argued that different individuals feed on the same prey but moved into the studied coastal habitats at different times, so that differences in stable isotope composition are simply a reflection of different times spent in these areas. Although this could be the case for females, it is not likely that this applies to males, as all seem to leave and return at approximately the same time each year. So, for males, the differences in stable isotope composition should not result from staggered arrival, and differ- 
ences in diet could be the cause of the observed differences in isotope values between individuals. However, because of the confirmed effect of movement, because not all females return every year, and because it is not known where females and males go for winter, differences in stable isotope composition could be driven by different past migrations, and it is not possible to confirm intrapopulation differences in diet. Therefore, this study lacks the detail necessary to conclusively determine if individual sharks are feeding on separate prey while in the coastal habitats of southeast Tasmania. If sevengills permanently resided in these areas, it would be easier to positively identify any intrapopulation differences in diet, but this was not the case, making the results somewhat ambiguous. Compound specific isotope analyses (e.g. Popp et al. 2007, Olson et al. 2010) and/or the use of a rapid turnover tissue such as liver or blood that reflects short-term, local feeding (MacNeil et al. 2006, Logan et al. 2006) could help resolve this question, but this was not possible due to logistic and ethical constraints. energetic and functional connectivity between otherwise discrete systems. As a top order predator, the presence of this migratory connectivity means that this species may regulate the overall community structure and dynamics in different systems through both direct and indirect interactions (Barnett et al. 2011). This has direct conservation implications for both this species and the different communities in which it is involved.

Acknowledgements. The authors thank L. Castles and C. Awruch for the help with collection of offshore samples, J. Yick and A. Pender for field assistance, the anonymous reviewers for the constructive comments on previous versions of the manuscript, and the Australian Animal Tagging and Monitoring System (AATAMS) for the loan of 12 receivers. All research reported complied with the laws of Australia. This project was funded by grants to A. Barnett from the Save Our Seas Foundation, Winifred Violet Scott Foundation and the Holsworth Wildlife Fund. Research was conducted under the Fisheries Permit No. 8028 (DIPWE, Tasmania), and Animal Ethics, University of Tasmania (\#A0009120).

\section{LITERATURE CITED}

\section{CONCLUSION}

Fish often show partial and differential migration patterns (Quinn \& Brodeur 1991), and this can hinder interpretation of trophic ecology and movement and residency studies based on stable isotope analysis. This can be further exacerbated for large, slow growing animals such as sevengill sharks. However, the combined use of stable isotope data with electronic tagging technology and dietary information allowed a better understanding of sevengill shark ecology in the area than the use of any one of the techniques alone. For example, if no movement information was available and only stable isotope and stomach content data were available, mixing models would probably have been used, leading to erroneous conclusions regarding sevengill diet and $\delta^{15} \mathrm{~N}$ trophic fractionation values for these sharks. Moreover, due to the relatively low cost, stable isotope analysis allowed a greater sample size to be analysed than was possible using the more expensive tracking methodology. Together, the different approaches confirmed that there are both intrapopulation differences in movement patterns and habitat use for sevengill sharks in southeast Tasmania. These differences are important when interpreting the ecological function of predator populations. The movement of these large top order predators between different habitats links well separated food webs, allowing an
Alfaro AC, Thomas F, Sergent L, Duxbury M (2006) Identification of trophic interactions within an estuarine food web (northern New Zealand) using fatty acid biomarkers and stable isotopes. Estuar Coast Shelf Sci 70:271-286

Austin D, Bowen WD, McMillan JI (2004) Intraspecific variation in movement patterns: modelling individual behaviour in a large marine predator. Oikos 105:15-30

$>$ Baird ME, Timko PG, Suthers IM, Middleton JH, Mullaney TJ, Cox DR (2008) Biological properties across the Tasman Front off southeast Australia. Deep-Sea Res I 55: 1438-1455

Barnett A, Stevens JD, Frusher SD, Semmens JM (2010a) Seasonal occurrence and population structure of the broadnose sevengill shark Notorynchus cepedianus in coastal habitats of south-east Tasmania. J Fish Biol 77: 1688-1701

> Barnett A, Abrantes K, Stevens JD, Yick J, Frusher SD, Semmens JM (2010b) Predator-prey relationships and foraging ecology of a marine apex predator with a wide temperate distribution. Mar Ecol Prog Ser 416:189-200

Barnett A, Abrantes KG, Stevens JD, Bruce BD, Semmens JM (2010c) Fine-scale movements of the broadnose sevengill shark and its main prey, the gummy shark. PLoS ONE 5:e15464

Barnett A, Redd KS, Frusher SD, Stevens JD, Semmens JM (2010d) Non-lethal method to obtain stomach samples from a large marine predator and the use of DNA analysis to improve dietary information. J Exp Mar Biol Ecol 393:188-192

> Barnett A, Abrantes KG, Stevens JD, Semmens JM (2011) Site-fidelity and sex-specific migrations in a mobile apex predator: implications for conservation and ecosystem dynamics. Anim Behav 81:1039-1048

Best PB, Schell DM (1996) Stable isotopes in southern right whale (Eubalaena australis) baleen as indicators of sea- 
sonal movements, feeding and growth. Mar Biol 124: 483-494

> Bolnick D, Svanback R, Fordyce J, Yang L, Davis J, Hulsey CD, Forister ML (2003) The ecology of individuals: incidence and implications of individual specialization. Am Nat 161:1-28

Bond AL, Diamond AW (2011) Recent Bayesian stableisotope mixing models are highly sensitive to variation in discrimination factors. Ecol Appl 21:1017-1023

$>$ Braccini JM (2008) Feeding ecology of two high-order predators from south-eastern Australia: the coastal broadnose and the deepwater sharpnose sevengill sharks. Mar Ecol Prog Ser 371:273-284

Caut S, Angulo E, Courchamp F (2008) Discrimination factors $\left(\Delta \delta^{15} \mathrm{~N}\right.$ and $\left.\Delta \delta^{13} \mathrm{C}\right)$ in an omnivorous consumer: effect of diet isotopic ratio. Funct Ecol 22:255-263

Caut S, Angulo E, Courchamp F (2009) Variation in discrimination factors $\left(\Delta^{15} \mathrm{~N}\right.$ and $\left.\Delta^{13} \mathrm{C}\right)$ : the effect of diet isotopic values and applications for diet reconstruction. J Appl Ecol 46:443-453

Cerling TE, Wittemyer G, Rasmussen HB, Vollrath F, Cerling CE, Robinson TJ, Douglas-Hamilton I (2006) Stable isotopes in elephant hair document migration patterns and diet changes. Proc Natl Acad Sci USA 103:371-373

> Cherel Y, Kernaléguen L, Richard P, Guinet C (2009) Whisker isotopic signature depicts migration patterns and multi-year intra- and inter-individual foraging strategies in fur seals. Biol Lett 5:830-832

Clementz M, Koch PL (2001) Monitoring habitat and foraging ecology in aquatic mammal with stable isotopes in the tooth enamel. Oecologia 129:461-472

Compagno LJV, Dando M, Fowler S (2005) Field guide sharks of the world. Harper-Collins, London

Connolly RM, Hindell JS, Gorman D (2005) Seagrass and epiphytic algae support nutrition of a fisheries species, Sillago schomburgkii, in adjacent intertidal habitats. Mar Ecol Prog Ser 286:69-79

Cortés E (1997) A critical review of methods of studying fish feeding based on analysis of stomach contents: application to elasmobranch fishes. Can J Fish Aquat Sci 54: 726-738

> Cortés E (1999) Standardized diet compositions and trophic levels of sharks. ICES J Mar Sci 56:707-717

Costanzo SD, O'Donohue MJ, Dennison WC (2003) Assessing the seasonal influence of sewage and agricultural nutrient inputs in a subtropical river estuary. Estuaries 26:857-865

Cunjak RA, Roussel JM, Gray MA, Dietrich JP, Cartwright DF, Munkittrick KR, Jardine TD (2005) Using stable isotope analysis with telemetry or mark-recapture data to identify fish movement and foraging. Oecologia 144: 636-646

Davenport SR, Bax NJ (2002) A trophic study of a marine ecosystem off southeastern Australia using stable isotopes of carbon and nitrogen. Can J Fish Aquat Sci 59: 514-530

> De'ath G, Fabricius KE (2000) Classification and regression trees: a powerful yet simple technique for ecological data analysis. Ecology 81:3178-3192

$>$ DeNiro MJ, Epstein S (1977) A mechanism of carbon isotope fractionation associated with lipid synthesis. Science 197: 261-263

DeNiro MJ, Epstein S (1981) Influence of diet on the distribution of nitrogen isotopes in animals. Geochim Cosmochim Acta 45:341-351
Ebert DA (1989) Life history of the sevengill shark, Notorynchus cepedianus (Peron 1807), in two Northern California Bays. Calif Fish Game 75:102-112

> Ebert DA (1991) Diet of the sevengill shark Notorynchus cepedianus in the temperate coastal waters of Southern Africa. S Afr J Mar Sci 11:565-572

- Ebert DA (2002) Ontogenetic changes in the diet of the sevengill shark (Notorynchus cepedianus). Mar Freshw Res 53:517-523

$>$ Estes JA, Tinker MT, Williams TM, Doak DF (1998) Killer whale predation on sea otters linking oceanic and nearshore ecosystems. Science 282:473-476

- France RL (1995) Carbon-13 enrichment in benthic compared to planktonic algae: foodweb implications. Mar Ecol Prog Ser 124:307-312

Fry B, Scalan RS, Parker PL (1983) ${ }^{13} \mathrm{C} /{ }^{12} \mathrm{C}$ ratios in marine food webs of the Torres Strait, Queensland. Mar Freshw Res 34:707-715

Herzka SZ (2005) Assessing connectivity of estuarine fishes based on stable isotope ratio analysis. Estuar Coast Shelf Sci 64:58-69

> Hindell MA, Bradshaw CJA, Sumner MD, Michael KJ, Burton HR (2003) Dispersal of female southern elephant seals and their prey consumption during the austral summer: relevance to management and oceanographic zones. J Appl Ecol 40:703-715

Hobson KA (1999) Tracing origins and migration of wildlife using stable isotopes: a review. Oecologia 120:314-326

Hussey NE, Brush J, McCarthy ID, Fisk AT (2010) $\delta^{15} \mathrm{~N}$ and $\delta^{13} \mathrm{C}$ diet-tissue discrimination factors for large sharks under semi-controlled conditions. Comp Biochem Physiol A 155:445-453

- Hyslop EJ (1980) Stomach contents analysis: a review of methods and their application. J Fish Biol 17:411-429

> Jaeger A, Lecomte VJ, Weimerskirch H, Richard P, Cherel Y (2010) Seabird satellite tracking validates the use of latitudinal isoscapes to depict predators' foraging areas in the Southern Ocean. Rapid Commun Mass Spectrom 24: 3456-3460

Jorgensen SJ, Reeb CA, Chapple TK, Anderson S and others (2009) Philopatry and migration of Pacific white sharks. Proc R Soc B 277:679-688

Last PR, Stevens JD (2009) Sharks and rays of Australia, 2nd edn. CSIRO Publishing, Collingwood

> Leeming R, Nichols PD (1998) Determination of the sources and distribution of sewage and pulp-fibre derived pollution in the Derwent Estuary, Tasmania, using sterol biomarkers. Mar Freshw Res 49:7-17

Logan JM, Lutcavage ME (2010) Stable isotope dynamics in elasmobranch fishes. Hydrobiologia 644:231-244

> Logan J, Haas H, Deegan L, Gaines E (2006) Turnover rates of nitrogen stable isotopes in the salt marsh mummichog, Fundulus heteroclitus, following a laboratory diet switch. Oecologia 147:391-395

> Lucifora LO, Menni RC, Escalante AH (2005) Reproduction, abundance and feeding habits of the broadnose sevengill shark Notorynchus cepedianus in north Patagonia, Argentina. Mar Ecol Prog Ser 289:237-244

MacAvoy SE, Macko SA, Garman GC (2001) Isotopic turnover in aquatic predators: quantifying the exploitation of migratory prey. Can J Fish Aquat Sci 58:923-932

- MacNeil MA, Drouillard KG, Fisk AT (2006) Variable uptake and elimination of stable nitrogen isotopes between tissues in fish. Can J Fish Aquat Sci 63:345-353 > Matich P, Heithaus MR, Layman CA (2011) Contrasting pat- 
terns of individual specialization and trophic coupling in two marine apex predators. J Anim Ecol 80:294-305

Matthews B, Mazumder A (2004) A critical evaluation of intrapopulation variation of $\delta^{13} \mathrm{C}$ and isotopic evidence of individual specialization. Oecologia 140:361-371

McConnaughey T, McRoy CP (1979) Food-web structure and the fractionation of carbon isotopes in the Bering Sea. Mar Biol 53:257-262

McClellan CM, Braun-McNeill J, Avens L, Wallace BP, Read AJ (2010) Stable isotopes confirm a foraging dichotomy in juvenile loggerhead sea turtles. J Exp Mar Biol Ecol $387: 44-51$

McMeans BC, Svavarsson J, Dennard S, Fisk T (2010) Diet and resource use among Greenland sharks (Somniosus microcephalus) and teleosts sampled in Icelandic waters, using $\delta^{13} \mathrm{C}, \delta^{15} \mathrm{~N}$ and mercury. Can J Fish Aquat Sci 67 : 1428-1438

Olson RJ, Popp BN, Graham BS, López-Ibarra GA and others (2010) Food-web inferences of stable isotope spatial patterns in copepods and yellowfin tuna in the pelagic eastern Pacific Ocean. Prog Oceanogr 86:124-138

Papastamatiou YP, Friedlander AM, Caselle JE, Lowe CG (2010) Long-term movement patterns and trophic ecology of blacktip reef sharks (Carcharhinus melanopterus) at Palmyra Atoll. J Exp Mar Biol Ecol 386:94-102

Phillips DL, Gregg JW (2003) Source partitioning using stable isotopes: coping with too many sources. Oecologia 136:261-269

Popp BN, Graham BS, Olson RJ, Hannides CCS and others (2007) Insight into the trophic ecology of yellowfin tuna, Thunnus albacares, from compound-specific nitrogen isotope analysis of protenaceous amino acids. In: Dawson $\mathrm{T}$, Siegwolf R (eds) Stable isotopes as indicators of ecological change. Elsevier/Academic, Amsterdam, p 173-190

Post DM (2003) Individual variation in the timing of ontogenetic niche shifts in largemouth bass. Ecology 84: 1298-1310

Post DM, Layman CA, Arrington DA, Takimoto G, Quattrochi J, Montaña GC (2007) Getting to the fat of the matter: models, methods and assumptions for dealing with lipids in stable isotope analyses. Oecologia 152:179-189

Quevedo M, Svanbäck R, Eklöv P (2009) Intrapopulation niche partitioning in a generalist predator limits food web connectivity. Ecology 90:2263-2274

Quinn TP, Brodeur RD (1991) Intra-specific variations in the movement patterns of marine animals. Am Zool 31: 231-241

> Ramos R, González-Solís J, Croxall JP, Oro D, Ruiz X (2009) Understanding oceanic migrations with intrinsic biogeochemical markers. PLoS ONE 4:e6236

Reid DD, Robbins WD, Peddemors VM (2011) Decadal trends in shark catches and effort from the New South Wales, Australia, Shark Meshing Program 1950-2010. Mar Freshw Res 62:676-693

> Revill AT, Young JW, Lansdell M (2009) Stable isotopic evidence for trophic groupings and bio-regionalization of predators and their prey in oceanic waters off eastern Australia. Mar Biol 156:1241-1253

Sherwood GD, Rose GA (2005) Stable isotope analysis of some representative fish and invertebrates of the Newfoundland and Labrador continental shelf food web. Estuar Coast Shelf Sci 63:537-549

Sotiropoulos MA, Tonn WM, Wassenaar LI (2004) Effects of lipid extraction on stable carbon and nitrogen isotope analyses of fish tissues: potential consequences for food web studies. Ecol Freshwat Fish 13:155-160

Van Dykhuizen G, Mollet HF (1992) Growth, age estimation and feeding of captive sevengill sharks, Notorynchus cepedianus, at the Monterey Bay aquarium. Aust J Mar Freshwater Res 43:297-318

> Vander Zanden MJ, Rasmussen JB (1999) Primary consumer $\delta^{13} \mathrm{C}$ and $\delta^{15} \mathrm{~N}$ and the trophic position of aquatic consumers. Ecology 80:1395-1404

Vander Zanden MJ, Rasmussen JB (2002) Food web perspectives on studies of bass populations in north-temperate lakes. Am Fish Soc Symp 31:173-184

Vanderklift MA, Ponsard S (2003) Sources of variation in consumer-diet $\delta^{15} \mathrm{~N}$ enrichment: a meta-analysis. Oecologia 136:169-182

Ward EJ, Semmens BX, Phillips DL, Moore JW, Bouwes N (2011) A quantitative approach to combine sources in stable isotope mixing models. Ecosphere 2:art 19

> Weng KC, Castilho PC, Morrissette JM, Landeira-Fernandez AM and others (2005) Satellite tagging and cardiac physiology reveal niche expansion in salmon sharks. Science 310:104-106

Appendix 1. $\delta^{15} \mathrm{~N}$ values of pelagic high trophic level predators in southeast Australia. Superscript letters indicate sources: (A) south of Tasmania, authors' unpublished data; (B) Davenport \& Bax (2002); (C) Revill et al. (2009). Values are mean \pm SE, with exception of data from Revill et al. (2009), for which mean \pm SD is presented

\begin{tabular}{|llc|}
\hline Species & Common name & $\delta^{15} \mathrm{~N}$ offshore (\%) \\
\hline Carcharodon carcharias & White shark & $14.7 \pm 0.3(4)^{\mathrm{A}}$ \\
Alopias vulpinus & Thresher shark & $13.5 \pm 0.1(2)^{\mathrm{B}}$ \\
& & $13.5(1)^{\mathrm{A}}$ \\
Prionace glauca & Blue shark & $13.6 \pm 0.2(14)^{\mathrm{C}}$ \\
& & $13.4 \pm 0.8(3)^{\mathrm{A}}$ \\
Isurus oxyrinchus & Shortfin mako & $13.5 \pm 0.3(3)^{\mathrm{B}}$ \\
Isurus paucus & & $13.7 \pm 0.4(21)^{\mathrm{C}}$ \\
Thunnus maccoyii & Longfin mako & $14.7(1)^{\mathrm{C}}$ \\
Xiphias gladius & Southern bluefin tuna & $14.3 \pm 0.2(17)^{\mathrm{C}}$ \\
Mean $( \pm \mathrm{SD})$ & Swordfish & $13.2 \pm 0.2(30)^{\mathrm{C}}$ \\
& & $13.8 \pm 0.5$ \\
\hline
\end{tabular}


Appendix 2. $\delta^{15} \mathrm{~N}$ values for species that were captured both in inshore areas of southeast Tasmania and in offshore areas of southeastern Australia. Values are mean \pm SE, with exception of data from Revill et al. (2009), for which mean \pm SD is presented. Numbers in brackets are sample sizes. Superscript letters indicate sources, as in Appendix 1, plus (D) this study. For Notorynchus cepedianus from this study, offshore includes individuals from the Shelf, Pedra Branca and Maatsuyker Islands, and coastal includes individuals from the Derwent Estuary, Norfolk Bay and Storm Bay

\begin{tabular}{|llccc|}
\hline Species & Common name & $\delta^{15} \mathrm{~N}$ offshore $(\%)$ & $\delta^{15}$ N coastal $(\%)$ & Difference in $\delta^{15} \mathrm{~N}$ \\
\hline Notorynchus cepedianus & Broadnose sevengill shark & $14.7 \pm 0.1(20)^{\mathrm{D}}$ & $16.2 \pm 0.1(127)^{\mathrm{D}}$ & +1.5 \\
Arctocephalus pusillus doriferus & Australian fur seal & $15.8 \pm 0.4(2)^{\mathrm{B}}$ & $16.6 \pm 0.1(3)^{\mathrm{D}}$ & +0.8 \\
Galeorhinus galeus & School shark & $13.3 \pm 0.5(13)^{\mathrm{B}}$ & $15.2^{\mathrm{D}}$ & +1.9 \\
Mustelus antarcticus & Gummy shark & $12.9 \pm 0.5(14)^{\mathrm{B}}$ & $14.2 \pm 0.1(39)^{\mathrm{D}}$ & +1.3 \\
Heterodontus portusjacksoni & Port Jackson shark & $12.0 \pm 0.4(6)^{\mathrm{B}}$ & $14.4 \pm 0.3(3)^{\mathrm{A}}$ & +2.4 \\
Cephaloscyllium laticeps & Draughtboard shark & $13.6 \pm 0.6(30)^{\mathrm{B}}$ & $15.7 \pm 0.1(3)^{\mathrm{A}}$ & +2.1 \\
Dasyatis brevicaudata & Smooth stingray & $13.9(1)^{\mathrm{B}}$ & $12.5 \pm 0.3(5)^{\mathrm{D}}$ & +0.1 \\
Dipturus confusus & Long nose skate & $12.4 \pm 0.8(6)^{\mathrm{B}}$ & $15.3 \pm 0.2(2)^{\mathrm{D}}$ & +2.9 \\
Narcine tasmaniensis & Tasmanian numbfish & $13.8 \pm 0.5(15)^{\mathrm{B}}$ & $14.6 \pm 0.2(5)^{\mathrm{D}}$ & +0.8 \\
Callorhynchus milii & Elephantfish & $10.3 \pm 0.2(2)^{\mathrm{B}}$ & $13.5 \pm 0.3(8)^{\mathrm{D}}$ & +3.2 \\
Conger verreauxi & Southern conger eel & $13.9 \pm 0.1(6)^{\mathrm{B}}$ & $16.6 \pm 0.4(6)^{\mathrm{D}}$ & +2.7 \\
Platycephalus bassensis & Sand flathead & $12.2 \pm 0.8(23)^{\mathrm{B}}$ & $14.2 \pm 0.3(11)^{\mathrm{D}}$ & +2.0 \\
Nototodarus gouldi & Gould's squid & $12.9 \pm 0.5(8)^{\mathrm{B}}$ & $14.6 \pm 0.2(12)^{\mathrm{D}}$ & +1.7 \\
Mean difference $( \pm \mathrm{SD})$ & & & & $1.9 \pm 0.9$ \\
\hline
\end{tabular}

Editorial responsibility: Yves Cherel, Villers-en-Bois, France
Submitted: March 30, 2011; Accepted: September 12, 2011 Proofs received from author(s): November 10, 2011 